\title{
Sweating blood: history and review
}

\author{
n Cite as: CMAJ 2017 October 23;189:E1315-7. doi: 10.1503/cmaj.170756
}

See related article at www.cmaj.ca/lookup/doi/10.1503/cmaj.161298

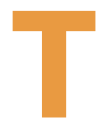

he case report in this issue of $C M A J^{2}$ raises two intriguing questions. First, do humans really sweat blood? Second, what is the medical history of this phenomenon?

Hematohidrosis has made brief but increasingly fewer appearances in dermatology texts. In 1895, Moritz Kaposi defined it as "the occasional spontaneous oozing of arterial blood from the sweat glands," and he cited observations by distinguished predecessors, including Ferdinand Ritter von Hebra. ${ }^{2}$ Referring to a 1930 article, two editions of Rook's Textbook of Dermatology (1968 and 1992) stated that it was "rare"; however, by 2007, the statement had vanished. In 2012 and earlier, Bolognia and colleagues, in their Textbook of Dermatology, declared that "hematidrosis," as a disorder of sweat glands, "has not been confirmed scientifically," although they did not deny its existence. On the other hand, standard hematology textbooks have long ignored hematohidrosis. When I asked some of my senior hematology colleagues at University of Toronto, Toronto, and Queen's University, Kingston, Ontario, if they had seen a case, none had, although two had witnessed bloody tears.

In answer to the first question, then, ambivalence is evident. Nevertheless, a steady stream of reports prompted the physician couple Joe E. Holoubek and Alice B. Holoubek, both devout Catholics, now deceased, to publish a 1996 classification

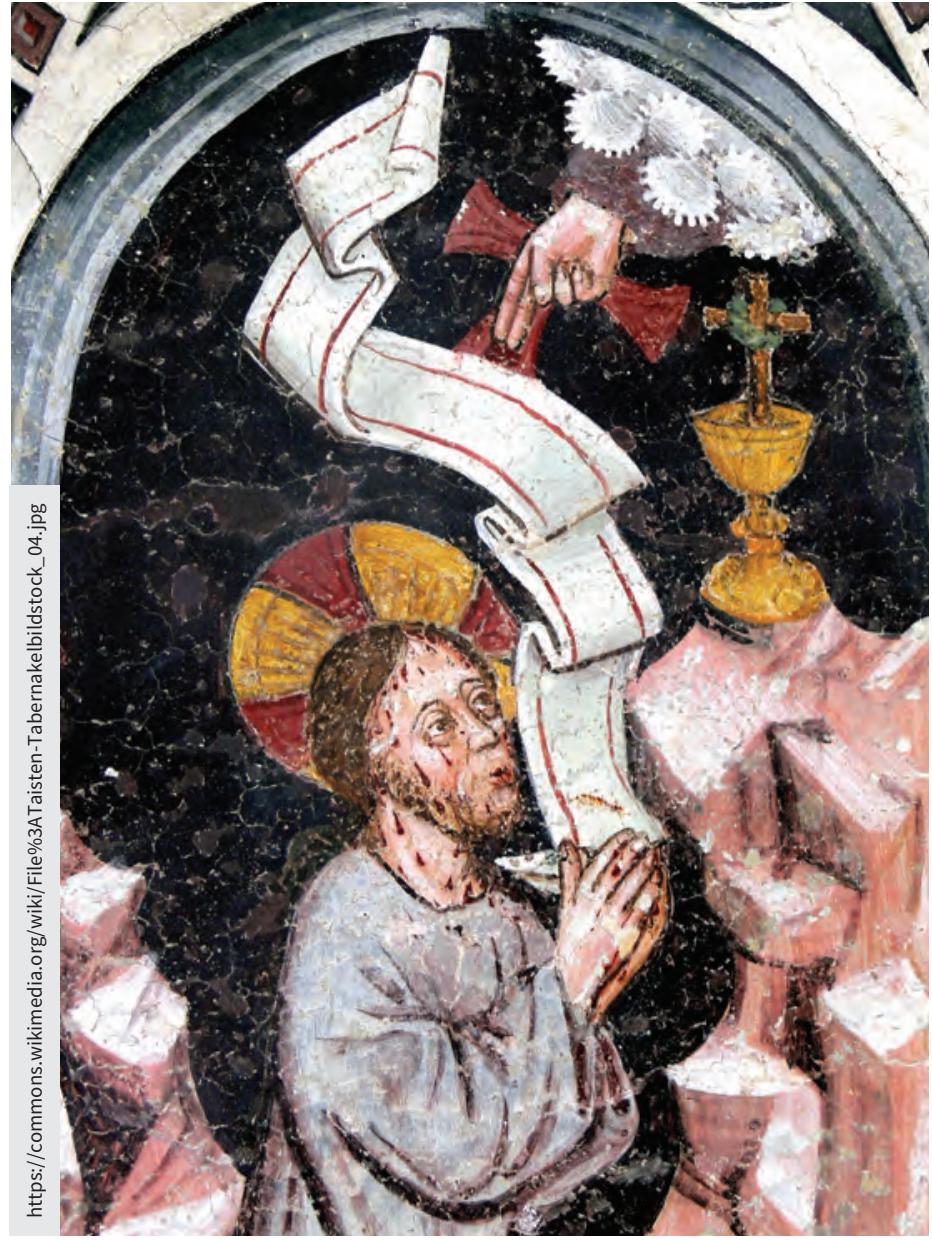

Tabernakelbildstock in Taisten. Christus am Ölberg [Wayside Shrine at Taisten, Italy: Christ on the Mount of Olives].

based on their careful review of 76 selected cases published from the 17th century to 1980. ${ }^{3}$ Historians quake at the irresistible practice of retrospective diagnosis, often calling it futile or condescending, because epistemic and social conditions change, diseases mutate and older descriptions lack parameters that are fundamental now: we must treat the experience of predecessors with respect and use our own views with humility. The Holoubeks navigated these challenges well, reminding us that credible, though scant, observations of sweating blood persist - as clinical phenomena of unspecified cause, if not as disease.

Regarding the second question about the clinical history of bloody sweat, medical writers often trace it to the story of Christ's suffering as told in the Bible by the physician evangelist (Luke 22:44). But hematohidrosis appeared in the scientific literature long before. ${ }^{4}$ As early as the third century B.C., two treatises by Aristotle contained passages about sweat that either looked like, or really was, blood.

Instances, indeed, are not unknown of persons who in consequence of a cachectic state have secreted sweat that resembled blood (Parts of Animals [3.5:668]).

If the blood get exceedingly liquid, animals fall sick; for the blood then turns into something like ichor, or a liquid so thin that at times has been known to exude through the pores like sweat (History of Animals [3:19]).

The opinion may have derived from the wisdom that some animals known to the ancients, such as the hippopotamus and certain horses, secrete red sweat long construed as blood. The physiologic possibility of bloody sweat also appeared in the work of Aristotle's successor, Theophrastus (On Sweat, 11-12). ${ }^{5}$

Many medical writers insist that the second-century Greek physician, Galen, described bloody sweat. But this assertion 
stems from the oft-repeated reference to the pseudo-Galenic Latin text, De utilitate respirationi. This treatise, which bears the same name as an authentic but different text, was paraphrased and popularized by the physician Richard Mead in his 1749 medical disquisition on the bloody sweat of Christ: "Contingere interdum, poros ex multo aut fervido spiritu adeo dilatari, ut etiam exeat sanguis per eos, fiatque sudor sanguineus. [It sometimes happens that the pores are so vastly dilated by a copious and fervid spirit, that even blood issues thro' them, and constitutes a bloody sweat]."

The passage does not describe a case; rather, it repeats Aristotle's view, emphasizing the etiological role of a "fervid spirit." It appears that the authentic Galen did not witness such a case, although his voluminous opus contains a great deal about blood and perspiration in relation to respiration. But blood as a humour, and sweat as its derivative, were of considerable importance in religion and literature throughout the middle ages. ${ }^{6}$ Chaucer described a horse ridden so hard that it "did sweat till men his coat might wring/His two flanks were all blood" ("Tale of Sir Thopas"). Skeptics of equine hematohidrosis might wonder about the role of abrasions.

In the late medieval and early modern periods, several physician authors referred to bloody sweat, but few presented original cases. Most described its possibility and plausibility, appealing to the physiologic authority of Aristotle and (pseudo-) Galen and referring to the passion of Christ. They include the 12-century Benedictine, William of Saint-Thierry, and the authors of several medical dissertations in Latin concerning "sudor cruentus" (bleeding sweat) and "sudor sanguineus" (bloody sweat). In most of these works, the purpose was to apply scientific knowledge to assess the plausibility and the naturalness of the story of the passion (Appendix 1, available at www.cmaj.ca/lookup/suppl/ doi:10.1503/cmaj.170756/-/DC1).

The scientific preoccupation with bloody sweat in this period might be related to a heated controversy surrounding one of the sacred relics of the church. Since the Middle Ages, the Veil of Veronica or Sudarium was reputed to be the cloth used to wipe Christ's face on his way to crucifixion; it retained an imprint of his fea- tures, possibly from sweat, or blood, or both. Notwithstanding its dubious origins, the veil was said to have hung in the old St. Peter's Basilica and been used in religious processions from at least the 13th century. After the 1527 sack of Rome, according to the scholars I. Wilson and E. Kuryluk, some thought it had been destroyed; others claimed it was taken elsewhere or lost, while yet others maintain it is still in St. Peter's. A brisk industry of making and selling copies arose, but by 1617 Pope Paul V had restricted their manufacture to designated authorities. In 1629, Pope Urban VIII ordered the destruction of all copies and excommunication for anyone daring to own one. The strict regulations surely enhanced the cachet of these objects. The parallel outpouring of medical and scientific interest in bloody sweat may have been stimulated by attempts to verify the claims of authenticity. It resembles the recent forensic investigations applied to the Shroud of Turin and various contenders for cloths that had once wrapped the same body, such as the Sudarium of Orviedo.

Notwithstanding their religious overtones, scattered throughout these early modern medical works appear the first eyewitness accounts of hematohidrosis, in what we would recognize as "case reports." For example, in 1627, Georg Spörlin, a physician from Basel, reported on a 12-year-old boy with a high fever who sweated blood through his shirt. ${ }^{7}$ In 1628 , the papal physician, Paolo Zacchia, described a young Belgian condemned to death who, in his anguish, sweated blood (Quaestiones medico-legales [Lib III, Tit II, Q II]). Several other writers observed the same phenomenon in prisoners facing execution. Samuel Ledelius described a case associated with scurvy. ${ }^{8}$

"Sudor cruentus" and "sudor sanguineus" appear in 18th- and 19th-century medical dictionaries. According to the Oxford English Dictionary, the various Greek-derived spellings of h[a]emat[oh] idrosis appeared more recently, in 1854. Another lesser-used term, "ephidrosis cruenta," also emerged in the mid-19th century. Because most observations had been made in women, some 19th-century authors, citing Gerard van Swieten and Philippe Pinel, favoured vicarious or suppressed menstruation as the cause; others, however, including George Gilles de la Tourette, invoked psychogenic factors and insisted that hematohidrosis was a product of hysteria. ${ }^{9}$ Later, doubt about that disease category itself probably led some to assume it was factitious.

Religious writers eventually cited the medical authors, as science lent credibility to gospel. For example, two theologians cited Richard Mead: Adam Clarke in his 1831 edition and commentary of the New Testament, and C. George Griffin's 1846 commentary on the Sufferings of Christ. The accumulation of religious and medical texts all citing each other influenced an erudite surgeon, J.H. Pooley of Toledo, Ohio, to compose an essay on bloody sweat for Popular Science magazine in January $1885 .{ }^{10}$ Drawing upon physician Mead, theologian Clarke and a number of other unreferenced sources, Pooley claimed that it had been described by Aristotle, Theophrastus and Galen, whom he piously cited in Latin. Then he briefly summarized more than 40 modern cases. Because this article is readily available online, pseudo-Galen, masquerading as Galen, is enjoying a renaissance in recent examinations of the subject.

A century later, the Holoubeks selected many of Pooley's cases for their extensive review. They identified several categories of conditions associated with hematohidrosis: systemic disease (e.g., scurvy and lupus), vicarious menstruation, physical exertion, psychological stress (repeated or unique), religious stigmatics and idiopathy. With the scant, second-hand descriptions, suspicion of underlying bleeding disorders or malingering remained. Only a handful of the Holoubeks' cases came from the 20th century. Consequently, few had been investigated to rule out coagulopathy or skin pathology.

\section{A recent review}

To assess the frequency of case reporting of the condition in modern times, a keyword search on "h[a]ematohidrosis" (also "hematidrosis" or "hemathidrosis") resulted in a list of 42 articles: 10 from the Index Catalogue of the Library of the Surgeon General, published from 1880 to 1935; and 32 from MEDLINE, published from 1952 to 2016, in reputable journals (mostly dermatological), including the International Journal of Dermatology and Blood. Until now, none have 
appeared in Canadian journals, although Canadians George Adami and John McCrae (physician poet who wrote "In Flanders Fields"), both of McGill University, mentioned it briefly as a form of cutaneous hemorrhage in their pathology textbook. Most of the articles were isolated case reports. The few that were not case reports are historical, retrospective diagnoses linking hematohidrosis to Christ's bloody sweat, the stigmata of St. Francis or Louise Lateau (1875), or the death by accidental poisoning of Charles IX of France, a story purveyed by Voltaire and immortalized by Alexandre Dumas in his novel, La Reine Margot (1845).

In discussion, several authors linked bloody sweat to hysteria or psychic causes, raising the question of its association with psychogenic purpura (Gardner-Diamond syndrome). ${ }^{11}$ Some continue to suggest that it is factitious, or a product of malingering, especially in articles from the early 20th century.

The 42 medical articles from 1880 to 2017 appeared at an average rate of one every three years. Of this total, however, five appeared in 2013, four in 2014, three in 2015, four in 2016 and two in 2017 (so far). In other words, almost half the total output from more than a century came in the last five years. Is the incidence of this condition increasing? Is it being more frequently recognized, as other causes or diagnoses are identified and eliminated? Does the "need to publish" goad authors to describe cases that they might otherwise have ignored? It seems unlikely that anyone who witnessed such a case would not want to write about it: as Thomas K. Chambers wrote in 1861, "I suppose since the invention of printing, very few examples of so strange a thing can have escaped being put into type."12

To revisit and update the Holoubek classification, the 28 new cases in the peerreviewed literature between 2004 and 2017 were analyzed. They came from nations on every continent, except North America. Twenty-four were female, four male. Most were young, with an average age of 14.1 years for females (range $7 \mathrm{mo}$ to $34 \mathrm{yr}$ ) and 26.5 years for the four males $(9,10,15$ and $72 \mathrm{yr}$ ) (Appendix 2, available at www.cmaj. ca/lookup/suppl/doi:10.1503/cmaj.170756/-/ DC1). Many were photographed.

All experienced transient but recurring bloody sweat from normal-appearing skin on multiple occasions through time, ranging from one month to four years. The most common sites were forehead, scalp, face, eyes and ears, but bloody sweat could also appear on the trunk and limbs, sometimes heralded by pain or tingling. Several had associated hypertension or headache. All were tested to confirm the presence of blood (as opposed to chemical discoloration) and to rule out bleeding disorders; only two displayed a coagulopathy (platelet factor 3 disorder in one patient and vitamin deficiency in another). Thirteen underwent skin biopsy, which was normal or showed nonspecific changes with blood cells in sweat ducts. At least 15 (54\%) had suffered severe psychological stress, either with mental illness, such as depression or anxiety, or in the posttraumatic setting, having witnessed violence at home, school or beyond (the abduction of a sibling; the beheading of a neighbour). Most patients were observed in one or more episodes by multiple medical observers whose suspicions that the symptom might be factitious were allayed. Vasculitis was hypothesized as an underlying cause in two cases, but never proven by biopsy. More often, the examples pointed to psychosomatic origins in mental anguish, the "fervid spirit" of pseudo-Galen via Mead. Some authors hypothesized varying sympathetic activity on microvasculature.

As for treatment, $\beta$-blockers were effective in six patients. Anxiolytics and antidepressants were also used in some, with variable results. An atropine skinwipe produced symptomatic relief for another; one patient who also had seizures improved after starting oxcarbazepine. Several cases resolved spontaneously. All authors emphasized the tremendous fear associated with hematohidrosis and the importance of reassurance. No one appears to have died of it. The report from Italy in $C M A J^{1}$ is typical: a young woman with debilitating psychic distress.

In sum, clinical reports of true hematohidrosis persist at a steady and possibly rising rate. This collection of well-documented observations commands respect and acceptance. But why - with all this evidence - do we still harbour doubts about its existence? Other rare conditions are not viewed with similar skepticism. Ironically, for an increasingly secular world, the longstanding association of hematohidrosis with religious mystery may make its existence harder to accept. It seems that humans do sweat blood, albeit far less often literally than metaphorically.

\section{Jacalyn Duffin MD PhD}

Hannah Chair of the History of Medicine, Queen's University, Kingston, Ont.

\section{References}

1. Maglie R, Caproni M. A case of blood sweating: hematohidrosis syndrome. CMAJ 2017;189: E1314.

2. Kaposi M. Pathology and treatment of diseases of the skin: for practitioners and students. Johnston JC, translator. London (UK): Bailliere. Tindall and Cox; 1895:118, 409.

3. Holoubek JE, Holoubek AB. Blood, sweat and fear. A classification of hematidrosis. J Med 1996;27:115-33.

4. Stolberg M. Sweat: learned concepts and popular perceptions, 1500-1800. In: Horstmanshoff M, King $\mathrm{H}$, Zittel C, editors. Blood, sweat and tears: The changing concepts of physiology from antiquity into early modern Europe. Leiden-Boston: Brill; 2012:503-22 (esp. 509).

5. Debru A. La sueur des corps: le De sudore de Théophraste face à la tradition médicale. In: Fortenbaugh WW, Wöhrle G, editors. On the opuscula of Theophrastus. Stuttgart (Germany): Franz Steiner Verlag; 2002:163-74 (esp. 168n23)

6. Bynum CW. Wonderful blood: Theology and Practice in Late Medieval Northern Germany and Beyond. Philadelphia: University of Pennsylvania Press; 2007.

7. Spörlin G. Letter [1627], in Wilhelm Fabricius Hildanus. In: Opera quæ extant omni. Frankfurt (Germany): Johannis Beyeri; 1646;601.

8. Ledelius S. in Manget JJ. Bibliotheca medico-practica sive rerum medicinarum thesaurus etc. Vol. 4. Geneva: Chouet and Ritter; 1697;592.

9. de la Tourette GG. Traité clinique et thérapeutique de l'hystérie d'après l'enseignement de la Salpêtrière. In: Part 1: Hystérie normale ou interparoxystique. Paris (France): Plon; 1891;438-58 (esp. 446-7).

10. Pooley JH. Bloody sweat. Popular Science Monthly 1885;26:357-65.

11. Ratnoff OD. Psychogenic purpura (autoerythrocyte sensitization): an unsolved dilemma. Am J Med 1989;87:16N-21N.

12. Chambers TK. Clinical Lecture on a case of "bloody sweat." Given at St. Mary's Hospital, Feb. 9th, 1861. Lancet 1861;77:207-9. (esp. 208).

This article was solicited and has been peer reviewed.

Additional resources are available in Appendix 3 (available at www.cmaj.ca/lookup/suppl/ doi:10.1503/cmaj.170756/-/DC1).

Acknowledgements: The author thanks Professors Paul Potter, Beate Gundert and Vivian Nutton for their Galenic wisdom; Dr. Belle Song for translation from Chinese; and Hissan Butt, Walton Schalick III, R.D. Wolfe and the anonymous readers for their comments. 